\title{
Feedback on the Feedback: Sociocultural Interpretation of Saudi ESL Learners' Opinions about Writing Feedback
}

\author{
Rami F. Mustafa \\ University of Exeter, Graduate School of Education \\ St Lukes Campus, Heavitree Road, EXETER EX1 2LU, UK \\ E-mail:rm365@exeter.ac.uk
}

Received: September 22, 2011

Accepted: October 10, 2011

Published: March 1, 2012

doi:10.5539/elt.v5n3p3

URL: http://dx.doi.org/10.5539/elt.v5n3p3

\begin{abstract}
This qualitative study employed informal conversational interviews and semi-structured individual interviews to capture the Saudi students' opinions about the feedback they receive, and about their perceptions on what constitutes helpful feedback. Sociocultural theory was used as the framework of this study. The findings suggest that the Saudi students do not think highly of the feedback, and that the feedback they desire is markedly different from what they receive. The students mentioned several impediments to feedback. From a sociocultural perspective, the feedback practices do not adhere to the best practices of the theory, resulting in major hindrances to the students' learning/writing development.
\end{abstract}

Keywords: Second language writing, Feedback, Sociocultural theory, Scaffolding, ZPD, Mediation

\section{Introduction}

One of the top priorities of being a teacher should be to constantly scrutinize whether or not our pedagogical practices meet the instructional expectations of students, which is especially true in the arena of L2 writing feedback, since the feedback "provides critical information to students about their writing performance" (Zamel, 1985, p. 80). Without this scrutiny, learning can be impaired (Brown, 2009; Schulz, 2001). The feedback wars between Truscott (1996, 1999, 2007) and Ferris and others (e.g., Chandler, 2003; Ferris, 1999; 2003; Bitchener, 2008; Bitchener \& Knock, 2008; Bitchener, Young, \& Cameron, 2005; Ellis, Sheen, \& Murakami, 2008; Sheen, 2007; Russell Valezy, \& Spada, 2006, among others) remain inconclusive, however, I believe that feedback can be helpful and can augment the skills of L2 writers (see also Ferris, 1995; Ferris, Pezone, Tade, \& Tinti, 1997; Flower, Hayes, Carey, Schriver, \& Stratman, 1986; Hyland, 1998; Hyland \& Hyland, 2006; Keh, 1990; Sommers, 1982; Elbow, 2002).

Commenting on the research on writing feedback, Hedgcock and Lefkowitz (1994) noted that "L2 educators are particularly interested in how teacher intervention in writing instruction influences the composing process, and more specifically, in how apprentice writers react to the feedback they receive on their immediate and final products" (p. 142). The authors reflect on the growing interest in deciphering student preferences, reactions, and perception of writing feedback, an area that has been little investigated (Ferris \& Roberts, 2001). In the same vein, Goldstein (2001) highlighted that research in the arena of feedback "has largely been non-contextual and non-social, focused largely on texts and conducted within a linear model of teacher respond and student revise" (p. 77), suggesting that feedback, as learning, is handed down (Riazi, 1997; Murphy, 2000; Goldstein, 2004; 2006). Nevertheless, a substantial amount of research operated on the principle of a paradigmatic shift that sees learning and teaching as essentially social activities (Cole \& Engestrom, 1993; Lantolf, 2000; van Lier, 2000; Block, 2003; 2007; Prior, 2006) rather than cognitive. The rationale for this view is that the cognitive paradigm is "too narrow in its understanding of context and was eclipsed by studies that attended to social, historical, and political contexts of writing" (Prior, 2006, p. 54). The driving force for applying the sociocultural theory (SCT) is that it "offers what is lacking in much literature on education - an effective conceptual metaphor for the quality of teacher intervention in learning" (Hammond, 2002, p. 2).

In this paper, I investigate and extend a sociocultural interpretation for: a) Saudi students' opinions about the writing feedback they receive from teachers, b) whether or not they consider the feedback as a mediating tool that can improve their writing skills, and c) their perceptions about what constitutes helpful feedback. The Saudi context is used because the data for this topic is scarce for this particular linguistically diverse group, only existing in the form of unpublished theses and electronic blogs. Only teacher feedback is considered, and other types of feedback (i.e., 
peer feedback) is beyond the scope of this study, since, according to Jacob, Curtis, Braine, and Huang (1998), 94\% of students prefer that the response to their writing comes from the teacher (and not peers), and because students expect, value, respect, and take their teachers' feedback more seriously.

\section{Insights from the Literature}

\subsection{Studies Looking at Feedback from a Sociocultural Perspective}

A growing body of literature uses sociocultural theory (SCT) as a theoretical underpinning for studying writing feedback (Adair-Hauck \& Donato, 1994; Aljaafreh \& Lantolf, 1994; Lantolf \& Pavlenko, 1995; Lalande, 1982; McGroarty, 1992; Murphy, 2000; Hyland \& Hyland, 2006). An often-cited example of how SCT can be applied to feedback can be found in Aljaafreh and Lantolf (1994), who examined the one-on-one interactions between three L2 learners and a tutor who provided corrective feedback on their essays. Aljaafreh and Lantolf developed a "regulatory scale" to reflect the extent to which the help provided by the tutor was implicit or explicit. Nassaji and Swain (2000), in a follow-up study, examined whether or not corrective feedback provided to two Korean L2 writers would improve their knowledge of English articles. They found that the corrective feedback given within the zone of proximal development (ZPD) was more effective than the feedback given irrespective of the learners' ZPD. Hyland (2000) clearly showed what happens when the teacher and the learner fail to establish the much needed intersubjectivity to build a ZPD. By analyzing the feedback practices and the learner responses of two teacher-student pairs, in terms of peer-feedback, Hyland revealed a mismatch between the goals of teachers and students. Hyland noted that the teachers treated writing drafts as "finished pieces" that needed "fixing up," whereas, the students found the feedback to be a means for enhancing their learning. Moreover, Hyland (2000) found that "cultural factors made them feel uncomfortable with the peer response situation and discouraged them from being critical of each others' work" (p. 52).

Vygotsky's basic tenets of SCT have been fully addressed in the literature, and need not be reproduced here. Nevertheless, in this section, I will refer to what constitutes feedback informed by SCT. Sociocultural feedback is a dialogic (language-mediated) interaction that enables an expert (teacher) to create a context in which novices can participate actively in their own learning and in which the expert can fine-tune the support that the novices are given (Anton, 1999). ZPDs, therefore, are opportunities that can be provided where the gap between learners' already assimilated knowledge or skills, and knowledge or skills yet to be assimilated, can be bridged when assisted (scaffolded) by a more advanced peer or teacher. ZPDs should be collaboratively created by knowing when to give help and when to withhold it through the interaction of the tutor and the student; successful ZPDs make the student assume responsibility and be less dependent. Feedback, accordingly, is said to be mediating if it props students to self-correct, and move away from relying on the teacher (other regulation) towards relying on self to notice and initiate repairs (self-regulation). In other words, language-mediated scaffolds implemented in the learner's ZPD are effective when "the learner's performance, including corrective behaviour is completely self-generated and automized and mistakes emanate from legitimate slips of the tongue, or the pen, rather than from incomplete learning" (Aljaafreh \& Lantolf 1994, pp. 470-471). Critical to our understanding of feedback is the opinion that feedback must be framed to map the transformation of understanding and not some end point. In other words, feedback viewed as a transient and fluid organism (see Wenger, 1998); therefore “... cognitive development [must be seen] as a process, as people move through understanding rather than to understanding (Rogoff, 1998, p. 690).

\subsection{Studies Tackling Student Reactions and Perspectives on Feedback}

This paper will focus only on two cohorts of research on feedback: studies aimed at establishing student preferences regarding instructor feedback (Hedgcock \& Lefkowitz, 1994; 1996; Leki, 1991; Radecki \& Swales, 1988; Saito, 1994); and studies investigating the reaction of students to feedback already received for their writing (Brice, 1995; Cohen, 1987; 1991; Cohen \& Cavalcanti, 1990; Ferris, 1995).

The reported findings for student opinions and reactions were far from being unified. Hounsell (1987) discovered that two opposing camps described the preferences: one was inclined towards meaning and the other was focused on structure and content. Saito (1994) and Radecki and Swales (1988) found out that feedback on grammar was the most useful; likewise, Leki (1991) reported that students disapproved of the teachers' feedback that was concentrated only on content and organization. Hedgcock and Lefkowitz $(1994 ; 1996)$ found that many L2 learners were concerned primarily with their problems in grammar and writing mechanics, and that feedback on content, organization, and style was of secondary importance to them. Other studies found that L2 learners desired a balance between content-based and language-based error feedback (Oladejo, 1993; Lee, 2005; Komura, 1999; Rennie, 2000).

As for students' opinions and what they do with the feedback they receive, Cohen (1987) reported that $80 \%$ of the students attended to the teachers' comments and feedback regarding grammar and writing mechanics; and pay even 
more attention to feedback on vocabulary, organization, and content. Moreover, 4 of the 15 students included in the study used feedback for revising their papers. Of the student sample, $17 \%$ thought that some parts of the feedback were vague and confusing, and most students made 'mental notes' from the feedback. In later studies, Cohen (1991) and Cohen and Cavalcanti (1990) corroborated the findings of Cohen (1987), with regards to the mental notes, and difficulty in understanding the teachers' comments. Lea and Street (2000) also found that students often interpreted comments differently from what was intended by the teacher, and the learners' opinions and perceptions about the effectiveness of the feedback depended on the L2 learning context.

Both Ferris (1995) and Brice (1995) reported findings that differed from those of Cohen $(1987 ; 1991)$ and Cohen and Cavalcanti (1990). Ferris (1995) reported that the students in her study used an assortment of strategies in dealing with their teachers' feedback: some students spoke to their teacher or friend about the feedback, others consulted grammar books and dictionaries, and other did nothing. Likewise, Brice (1995) reported that students who were engaged in reading, responded to their teachers' commentaries and planned to incorporate the comments in their revisions.

In the literature, many research studies report that students desire feedback to be more indirect, using error "codes" and "clues" (Saito, 1994; Ferris \& Roberts, 2001; Arndt, 1993; Komura, 1999; Rennie, 2000); however, Brice (1995), Leki (1991), and Radeckie and Swales (1985) found that students disliked the coding system and preferred explicit feedback. Other studies revealed that students appreciated positive feedback (Cohen \& Cavalcanti, 1990) over negative comments that they found to be frustrating (Ferris, 1995). The question of the significance of student-teacher conferences was also discussed (Arndt, 1993; Zamel, 1985). Other researchers (Cathcart \& Olsen, 1976; Ferris, 1995; Lee, 2005; Radecki \& Swales, 1988) mentioned that L2 learners preferred large amounts of feedback as opposed to occasional or selective feedback.

\subsection{Studies Looking at Feedback in a Saudi Context}

As mentioned in the introduction, few studies have investigated student opinions and perceptions on writing feedback, and the scarcity of data does not allow for a clear picture of this specific linguistic group. Three unpublished theses; specifically, Grami's (2004) MA thesis that looked at the reactions of Saudi students to their teachers' feedback; Grami's (2010) PhD thesis that explored the perceptions of Saudi students of peer-feedback; and Asiri's (1997) $\mathrm{PhD}$ thesis investigating the reaction of Saudi students to teacher feedback, revealed that Saudi students were satisfied with their teachers' feedback and that their writing improved. In addition, two, published research papers (Grami, 2005; Al-Qurashi, 2009) looked at the matter from the perspective of Saudi students and found that the students had positive reactions to giving and receiving comments about their writings. Moreover, the collaborative feedback aided the students in mastering writing tasks as a process (Al-Qurashi, 2009), and that Saudi students felt strongly about the importance of writing feedback and feedback on surface-level errors (Grami, 2004). The three theses and the two research papers are significant for shedding light on the Saudi context, even though the samples of students were limited to those from English Departments.

\section{Methodology}

\subsection{Study Design}

This research is a small-scale qualitative study, following a naturalistic paradigm to capture and interpret student perspectives on writing feedback. By adopting this design, the researcher sought to understand meaning from the students' point of view in a non-controlling and open way (Patton, 2002). Qualitative methods were used because they are "... most often used to understand the cultural or everyday practices of individuals and social groups" (Schultz, 2006, p. 359) To fulfill that goal, informal conversational interviews, in addition to semi-structured open-ended question interviews were used to collect data.

\subsection{Research Questions}

1. What kind of feedback do Saudi students receive? And what are their opinions about it?

2. What Kind of feedback do Saudi students want to receive?

\subsection{Study Context}

The study was conducted in a private ESL school in Vancouver, Canada. Saudi students in the school attend two different kinds of classes: 1) mainstream ESL classes that are multicultural in nature; and 2) Power Writing classes (from Monday to Thursday) that are tailored for the Saudi students, upon the request of the Saudi Cultural Bureau. The focus of this study is on the Power Writing classes; specifically, the IELTS Power class (Class A had 16 students and Class B had 15 students). The IELTS students were chosen because they constitute the majority of Saudi students with a high level of English language competency. 


\subsection{Research Participants}

To select information-rich participants for this study, I adopted the 'Maximum Variation Sampling' technique so that multiple perspectives of individuals can be presented, exemplifying the complexity of the world (Creswell, 2002). The sample was comprised of subjects representing both sexes, and a variety of ages and previous educational contexts (Table 1). No students were included if they were being tutored by private instructors, to ensure that the gathered data was only related to the IELTS classrooms. Ultimately, five Saudi IELTS students were chosen (Table 1, Appendix B).

\section{Data Collection Instruments and Analysis}

\subsection{Interviews}

At first, "informal conversational interviews" (Patton, 2002) were conducted, with only a general predetermined topic, which allowed for probing questions. A total of two informal conversational interviews were conducted. The interviews were digitally recorded, and field notes were taken to augment the recordings. Thematic Content Analysis (Daly, Kellehear, \& Gliksman, 1997) was used to analyse the transcripts of the interviews to ensure that the thoughts and feelings of the participants were being represented in an honest way. This process included reading materials more than once, taking notes, and highlighting excerpts of the interviews, to represent the students' perceptions about feedback.

The individual interviews were used to allow the interviewees some freedom to explain their thoughts and to highlight any particular areas of interest or expertise that they might have had. The semi-structured interviews were used to allow for further investigation of certain responses. Since the interviews were the primary sources of data, major questions were developed in the form of main questions which were then followed-up with sub-questions for further probing (Appendix A). The interviews were conducted two weeks after the first informal conversational interviews, over the course of two weeks in a private classroom. Each interview lasted approximately 30 minutes. The transcribed data was analyzed and thematically categorized. A qualitative content analysis (Berg, 2004) was carried out by the author.

All of the interviews were conducted in Arabic language to ensure that the students would fully express themselves. All interviews were digitally audio-taped. The interviews were transcribed in Arabic and then translated into English. The transcribed data (in Arabic) was given to the students to verify the content and approve it.

\subsection{Findings}

This section summarizes the students' opinions and perceptions about the feedback they receive from their teachers and whether or not they think it is helpful.

\subsection{Actual Feedback}

Do Saudi students believe that the feedback they receive had an impact on their learning/writing process? In a word, no. The responses of students were predominantly negative regarding the efficacy of feedback, with all interviewees indicating that the feedback they received did not improve their writing skills, nor did it give them any new knowledge. The students believe that the nature of the feedback practiced by their teachers hinders the efficacy of feedback. The responses revealed the students' discontent about the feedback in terms of efficacy and practices. The use of feedback was not achieving the hoped-for long-term aims of students. Typical comments were:

"With or without feedback, my writing level is the same" (Abdullah)

"The only benefit I get from the feedback right now is a reminder that my grammar is weak" (Muneerah).

The types of error that were targeted by feedback constituted one of the red-hot discussions. Two cohorts of opinion surfaced: the first cohort described the teachers' feedback as purely focused on grammatical errors and mechanical issues, such as punctuation and capitalization. The following comments represent the argument for the first cohort:

"little or no focus on ideas, stylistics, arguments or even organization, which in my opinion is pivotal" (Muneerah)

“... mainly focused on grammatical and punctuation marks, while writing has in it more than grammar I think" (Majid)

The second cohort, however, was represented by comments such as, the feedback was focused on:

"errors that I can easily detect myself had I the time to revise and reflect"(Jawaher)

"errors that doesn't even affect the meaning. You still can understand what is meant" (Abdullah).

At the same time, a general agreement was expressed by students that the frequency of feedback is a problem. Majid commented: 
"once in every blue moon feedbacks don't help simply because by the time I receive the feedback, I already forgot the topic or the situation."

The students suggested that teachers need to work on delivering timely feedback because delayed feedback "is a waste of time" (Muneerah). Stressing the importance of timely feedback, Majid, used a medical metaphor to argue that

"writing errors are our cancer; and delaying the chemotherapy (the feedback) will either lead to long haul suffering and eventually death."

The students conveyed a close link between feedback legibility and efficacy, which was seen in their comments describing feedback as cryptic, which are illegible in terms of teachers' written comments, or for showing the meaning of the feedback:

"my teacher uses symbols and codes" (Ali)

"I cannot decipher my teacher's handwriting" (Muneerah)

Abdullah wryly comments:

"I feel like I am in a cryptology classroom. I have to decipher the code before proceeding to the clue."

Several references were made to different feedback methods which did not meet student approval. For example, all students shared their loathing of the code, which was described as "cryptic," claiming that:

"it is frustrating and drives me away from even considering the feedback (Jawaher).

Criticizing the practice of just underlining an error and/or labelling it, and presupposing that it is enough for the students to correct them on their own, Abdullah said:

"I am not psychic. Tell me, bluntly what the error is and how to fix it."

Generally, the students preferred direct feedback. Majid, however, commented on the misleading dimension of 'selective feedback' by pointing out that

"when he [the teacher] selects some errors and underlines them, he gives me the impression that everything else if OK. And the truth is far from that."

Overall, the results indicate that the only possible "learning" the students might be doing, was to know what the errors are, but the teaching practice is not welcomed as a "learning opportunity".

One of the teaching practices that was heavily criticized was text appropriation, or "text hijacking" as it was called by Abdullah, who pointed to the problem:

“... my teacher hijacks my writing. He underlines pieces, and sometimes long pieces, of my writing and rewrites them again, and concludes his rewriting with 'this is how a native speaker would do it' want my ideas to be intact and corrected".

Students were slightly reserved about the overreliance on peer feedback, with their biggest concern being that other students are not well equipped to give writing feedback. One student said:

"They [other students] may not detect the errors, and they correct my error with another error based on their understanding that they are correct. I guess feedback should come from the teacher mainly" (Ali).

To the Saudi students, 'writing feedback' meant being stereotyped. The first group of comments in this regard were clustered around the fact that teachers give feedback based on preconceived ideas rather than on tangible evidence collected from classroom performances. Muneerah, for example, argued that her writing teacher believes that that

"he/she is Saudi, their feedback should primarily focus on grammar, because all Saudis are weak in grammar,"

The second group targeted the issue of work ethics in the classroom. Majid said:

"my teacher thinks we lack the desire to learn," and Jawaher said, "my teacher thinks we are being spoiled since we have full scholarships, therefore, we are not serious; so why should he be?"

Nevertheless, the third group of comments had more advice, rather than complaints. Abdullah said:

"the [stereotypes] should not stigmatize students and prevent them from many benefits they would have gotten if their teachers hadn't stereotyped them. Even if those stereotypes were correct, teachers should use them as symptoms for better interventions."

At the heart of the students' frustration was the idea,

"we are in the dark when it comes to the feedback, I mean, the teacher decides what is best for us and that's it" 
(Ali).

This opinion shows that the students disapprove of the teachers' unilateral design and application of feedback, saying that it is an act of individualism on the part of the teacher:

"it deprives me from having a say in my education" (Majid).

The sheer volume of student opinion in this area indicates that the lack of socialization and the absence of common ground between the involved stakeholders create an atmosphere of disengagement in the classroom as a community of practice.

\subsection{Desired Feedback}

For the students, optimum feedback on writing should be timely, comprehensive, detailed, versatile, and legible in its delivery and meaning. A consensus was expressed that feedback should go beyond mere identification of errors and offer solutions to fix them. Jawaher said that

"teachers must go far and beyond underlining the error or labelling it, they should train us how to avoid doing the same error over and over again."

Muneerah suggested that the teachers suffer from

"the rubber stamp syndrome"

which means the teachers over-consume the same feedback techniques. She believes that

“teachers'feedback should be versatile and appropriate to the kind of error. After all, feedback panacea does not exist."

The importance of having feedback on both content and grammar was accentuated by all students. One student said,

"if your grammar is intact, but your ideas are trivial; you will not achieve anything. And if you have tonnes of ideas and your grammar is weak, you are not going anywhere. I believe I need feedback on both; however, more focus on ideas" (Abdullah).

In this area, two of the students, Jawaher and Majid, mentioned that the use of model essays is very helpful. When asked to define model essays, Majid said that they are

"essays written by native speakers, or Native English speaking teachers."

As a reason for using model essays, Jawaher argued that

"as a non-native speaker of the English language, I am really interested in reading and seeing how native speaking people tackle these issues."

It was emphasized earlier that receiving the feedback by itself is ineffective and does not instigate development, and that oral feedback is necessary to augment written comments and maximize the benefit. The students conveyed their desire for student-teacher conferences for

"negotiating the feedback, explain the weaknesses, and get further directions for better achievements" (Majid).

These opinions are echoed by Ali's call for a

"participatory feedback process in which teachers and students engage in a dialogue to devise a common agenda, and create mutual understanding for each other's aims of the feedback."

\section{General Discussion}

The results of this study provide three main insights: students' opinions about teacher feedback, factors that impede the efficacy of feedback, and the students' desired feedback.

\section{Saudi students' opinions about feedback}

First, the results of this study are consistent with those of past research (Goldstein, 2006; Montgomery \& Baker, 2007; Furneaux, Paran, \& Fairfax, 2007; Lefkowitz, 2008; O’Donnell, 2007), the Saudi students were not satisfied with the feedback they received from their teachers, but regardless of their reactions to the types of feedback they receive and prefer, they still appreciated it and took it seriously (e.g., Cohen \& Cavalcanti, 1990; Leki, 1991; Hedgcock \& Leftkowitz, 1994; Ferris, 1995; Hyland, 1998; Ferris \& Roberts, 2001; Lee, 2004). Although it is quite daunting for teachers to cater to the expectations of every student, this was not the case in this study. None of the student responses in this study were positive in any sense. The results could be 'the tip of the iceberg' as they suggest a more complex situation happening for a few unhappy students, possibly including a lack of proper teacher training, for example. 


\section{Feedback Impediments}

In discussing the impediments to feedback, the students mentioned a wide spectrum of reasons. The students' view is that feedback that focuses on grammar and writing mechanics is quite substantive, since the number and types of comments showed an alarming number of problems; however, content should be also targeted. Several feedback taxonomies, e.g., "global" vs. "local" errors (Burt, 1975), and "untreatable" vs. "treatable" (Ferris, 1999) have been discussed in the literature. Most studies indicate that students prefer a lot of comments (e.g., Leki, 2006), especially on local issues (e.g., Cohen, 1987). In fact, the students in this study thought that the teacher gave a 'scarce' amount of feedback on content and called for a more equal amount of attention to different problems (Fathman \& Whalley, 1990; Ferris, 1997). Thus, the teachers may not be aware that they are focusing more on local issues, or may believe that this kind of feedback is specifically needed for this group of students. Moreover, the significance of the indirect feedback was also questioned by the students. The findings in this area are mixed and incoherent. For example, Robb, Ross and Shortreed (1986) reported no differences for type of feedback; whereas Lalande (1982) found that students who received indirect feedback had greater gains than those who received direct corrections. Chandler (2003), however, reported greater benefits in accuracy for students who received direct feedback over those who received one of three forms of indirect feedback.

The study also found that teacher feedback is confusing, frustrating, and ultimately ineffective (Sommers, 1982; Zamel, 1985; Conners \& Lunsford, 1993). Researchers have suggested that students might misunderstand the feedback (Ferris, 1995; Conrad \& Goldstein, 1999) or might be unable to successfully generate the correct revisions. Moreover, in this study, ample evidence supports Sommer's (1982) idea that 'teacher comments can take students' attention away from their own purpose in writing a particular text and focuses attention on the teachers' purpose of commenting" (p.149). This suggests that teachers do not take the necessary steps for understanding what the students are hoping to achieve, consequently, they respond inappropriately (Goldstein, 2004). Other issues included stereotyping students and the lack of classroom interaction.

Moreover, the students described their teachers' behaviour in accordance with what Whitfield and Pollard (1998) mentioned as the ESL situation in Saudi Arabia, which is a 'pre-communicative practice' in a community that is content-focused, and teacher-dependent. Stereotyping led the teachers to hold inaccurate perceptions (for the purpose of saving time and effort) about the students' learning traits, and that lead to inaccurate provision of feedback that does not meet the students' needs. Moreover, stereotyping stigmatized the learners more than it helped them (Horowitz, 1986; Johns, 1995; James, 1998).

The feedback practices and the resulting impediments were clear indicators of student disengagement, as discussed by Ellis (2010, p. 342). This can be manifest in three ways: 1) cognitively, in the sense that students were disinterested in the feedback practices and the process as a whole; 2) behaviourally, by choosing to ignore the offered feedback and not incorporating it in future revisions: and 3) affectively, by being demotivated, frustrated, and even angry.

\section{Saudi students' desired feedback}

The third insight suggested by this study was that the Saudi students desired feedback that was completely different from what was offered, which is a strong indicator of the absence of socialization in the classroom. Successful teachers need to consider their students' perceptions and visions regarding feedback, and try to align their practices towards those perceptions. The failure to do so could be detrimental, as the students might shut down psychologically, which would bring the whole process to a standstill (Leki, 1991). Nevertheless, Brown (1998) warns that student preferences should not be idolized, since they might "not necessarily be more effective" (p. 253).

The feedback practices were clearly not adhering to the tenets of sociocultural theory, as discussed in the literature review. To begin, Lantolf (2000, p.1) highlighted that "We also use symbolic tools, or signs, to mediate and regulate our relationship with others and with ourselves and thus change the nature of these relationships (my italics)... included among symbolic tools are numbers and arithmetic systems, music, art, and above all language." The feedback practices provided only 'affordances' for mediating, rather than mediation since the feedback failed to regulate the relationship between the teachers and students on the one hand, and between the student and the writing on the other hand. Moreover, Aljaafreh and Lantolf (1994) claim that mediation needs to be contingent, i.e., teachers need to balance the giving and withholding of assistance according to the students' progression through a task. This is exactly opposite to what has been described as the "rubber-stamp feedback" (see also Stetsenko and Arievitch, 2002). Feedback, in my perspective, fits the idea of situated learning in a community of practice composed of experts and novices (Lave \& Wenger, 1991; Wenger, 1998), where interaction is the soul of the learning. Again, the practices deprived students from having a voice, since the practice was unilateral. As a consequence, an "imposition of a structure on the students" was created (Stone, 1998, p. 349). In addition, STC stipulates that learners are helped 
to move into the ZPD and then beyond it to a new and higher level, which provides a new ZPD, to imply a capacity for more development at every stage (Pichard \& Woolward, 2010).

\section{Conclusion and Limitations}

First, although students in the study appreciated the teacher feedback and found it somewhat useful, they were uncertain about its effectiveness for improving their writing in the long-run. The teachers invested mostly in feedback about local errors, and even so, the students felt that the feedback was not showing them how to fix the errors. Moreover, the feedback failed to involve students in the process, and the feedback techniques were not sufficiently eclectic. In addressing these points, the students mentioned that a greater variety of feedback, and student-teacher conferences, might be useful strategies to improve the situation.

The mismatches between students and teachers, that were seen in this study, could be a good starting place for researchers to gain insight about the applications of SCT in writing feedback. The paradigm of writing feedback needs to be shifted from its individualistic boundaries to become more dynamic and social.

In this study, several limitations should be considered. First, the study was focused solely on student opinions and perceptions, even though teacher input was important and the results would be relevant to the teachers. Second, only the Saudi students who were preparing for the IELTS test participated in the study. Other limitations include the lack of considering issues like the washback effect, or the class size effect on feedback.

\section{References}

Adair-Hauck, B., \& Donato, R. (1994). Foreign language explanations within the zone of proximal development. Canadian Modern Language Review, 50, 532-557

Aljaafreh, A., \& Lantolf, J. P. (1994). Negative feedback as regulation and second language learning in the zone of proximal development. The Modern Language Journal, 78, 465-483. http://dx.doi.org/10.1111/j.1540-4781.1994.tb02064.x

Al-Qurashi, F. (2009). Saudi students' reactions to peer response groups in EFL composition classrooms. Journal of King Saud University-Languages and Translation, 21, 57-67

Anton, M. (1999). A learner-centered classroom: Sociocultural perspectives on teacher-learner interaction in the second language classroom. The Modern Language Journal, 83, 303-318. http://dx.doi.org/10.1111/0026-7902.00024

Arndt, V. (1993). Response to writing: Using feedback to inform the writing process. In M. N. Brock, \& L. Walters (Eds.), Teaching composition around the Pacific Rim: Politics \& pedagogy (pp. 90-116). Clevedon, Avon, UK: Multilingual Matters.

Berg, B. L. (2004). Qualitative research methods for the social sciences, $5^{\text {th }}$ ed. Boston: Allyn and Bacon.

Berg, B. L. (2001). Qualitative research methods for the social sciences. London: ALLYN and BACON.

Bitchener, J. (2008). Evidence in support of written corrective feedback. Journal of Second Language Writing, 17(2), $102-118$

Bitchener, J., \& Knoch, U. (2008). The value of written corrective feedback for migrant and international students. Language Teaching Research, 12(3), 409-431

Bitchener, J. S. Young, \& Cameron, D. (2005). The effect of different types of corrective feedback on ESL student writing. Journal of Second Language Writing, 9(3), 227-258

Block, D. (2003). The social turn in second language acquisition. Edinburgh: Edinburgh University Press.

Block, D. (2007). The rise of identity in SLA research, Post Firth and Wagner (1997). The Modern Language Journal, 91, 863-876. http://dx.doi.org/10.1111/j.1540-4781.2007.00674.x

Brown, C. (1998). Errors in language learning and use: Exploring error analysis. London: Longman.

Brown, A., \& Reeve, R. (1987). Bandwidths of confidence: The role of supportive contexts in learning and development. In L. Liben (Ed.), Development and learning: Conflict or congruence (pp. 173-223). Hillsdale, NJ: Lawrence Erlbaum.

Brown, A. L., \& Ferrara, R. A. (1985). Diagnosing zones of proximal development. In J. Wertsch (Ed.), Culture, communication and cognition: Vygotskian perspectives (pp.273-305). Cambridge: Cambridge University Press.

Brice, C. (1995). ESL writers' reactions to teacher commentary: A case study. Paper presented at the Annual Meeting of the Teachers of English to Speakers of Other Languages, Long Beach, CA (Eric Document Reproduction 
Service No. ED 394 312)

Burt, M. (1975). Error analysis in the adult EFL classroom. TESOL Quarterly, 9, 53-63

Cathcart, R. L., \& Olsen J. W. B. (1976). Teachers' and students' preferences for correction of classroom conversation errors. In J. F. Fanselow, \& R. H. Crymes (Eds.), On TESOL, 76, (pp. 41-53). Washington, D.C. TESOL.

Cazden, C. B. (1988). Classroom discourse: The language of teaching and learning. Portsmouth, NH: Heinemann.

Chandler, J. (2003). The efficacy of various kinds of error feedback for improvement in the accuracy and fluency of L2 student writing. Journal of Second Language Writing, 12(2), 267-296

Cohen, A. D. (1987). Student processing of feedback on their compositions. In A. L. Wenden, \& J. Rubin (Eds.), Learner strategies in language learning (pp. 57- 69). Englewood Cliffs, N. J. Prentice-Hall.

Cohen, A. D. (1991). Feedback on writing: The use of verbal report. Studies In Second Language Acquisition, 13(2), 133-157

Cohen, A. D., \& Cavalcanti, M. C. (1990). Feedback on compositions: Teacher and student verbal reports. In B. Kroll (Ed.), Second language writing: Research insights for the classroom (pp. 155-177). Cambridge: Cambridge University Press.

Cohen, D., \& Crabtree, B. (2006). Qualitative research guidelines project. [Online] Available: http://www.qualres.org/HomeInfo-3631.html

Cole, M., \& Engestrom, Y. (1993). A cultural approach to distributed cognition. In G. Salmon (Ed.), Distributed cognitions: Psychological and educational considerations (pp. 1-46). New York: Cambridge University Press.

Connors, R. J., \& Lunsford, A. (1993). Teachers' rhetorical comments on student papers. College Composition and Communication, 44, 200-223

Conrad, S. M., \& Goldstein, L. M. (1999). ESL student revision after teacher written comments: Text, contexts and individuals. Journal of Second Language Writing, 8, 147-179. http://dx.doi.org/10.1016/S1060-3743(99)80126-X

Creswell, J. W. (2002). Educational research: Planning, conducting, and evaluating quantitative and qualitative research. Upper Saddle River, NJ: Pearson Education.

Daly, J., Kellehear, A., \& Gliksman, M. (1997). The public health researcher: A methodological approach. Melbourne, Australia: Oxford University Press.

Daniels, H. (2002). Literature circles: Voice and choice in the student-centred classroom (2 ${ }^{\text {nd }}$ ed.). Portland, MN: Stenhouse Publishers.

Dohrer, G. (1991). Do teachers' comments on students' papers help? College Teaching, 39(1), 48-54

Donato, R. (1994). Collective scaffolding in second language learning. In J. P. Lantolf, \& G. Appel (eds), Vygotskian Approach to Second Language Research. Norwood, N.J. Ablex Publishing Corporation.

Elbow, P. (2002). High stakes and low stakes in assigning and responding to writing. In G. DeLuca, L. Fox, M.-A. Johnson, \& M. Kogen (Eds.), Dialogue on writing: Rethinking ESL, basic writing, and first-year composition (pp. 289-298). Mahwah, NJ: Lawrence Erlbaum Associates.

Ellis, R. (2010). A framework for investigating oral and written corrective feedback. Studies in Second Language Acquisition, 32, 335- 349

Ellis, R., Sheen, Y., Murakami, M., \& Takashima, H. (2008). The effects of focused and unfocused written corrective feedback in an English as a foreign language context. System, 36(3), 53-371

Ferris, D. R. (1995). Student reactions to teacher response in multiple-draft composition classrooms. TESOL Quarterly, 29, 33-53

Ferris, D. R. (1999). The case for grammar correction in L2 writing classes. A response to Truscott (1996). Journal of Second Language Writing, 8(1), 1-10

Ferris, D. R. (2003). Response to student writing: Implications for second language students. Mahwah, NJ: Lawrence Erlbaum.

Ferris, D. R. (2010). Second language writing research and written corrective feedback in SLA: Intersections and Practical Applications. Studies in Second Language Acquisition, 32, 181-201

Ferris, D., Pezone, S., Tade, C., \& Tinti, S. (1997). Teacher commentary on students writing: Descriptions and 
implications. Journal of Second Language Writing, 6(2), 155-182

Ferris, D., \& Roberts, B. (2001). Error feedback in L2 writing classes: How explicit does it need to be? Journal of Second Language Writing, 10(3), 161-184

Flower, L., Hayes, J., Carey, L., Schriver, K., \& Stratman, J. (1986). Detection, diagnosis, and the strategies of revision. College Composition and Communication, 37(1), 16-37

Furneaux, C., Paran, A., \& Fairfax, B. (2007). Teacher stance as reflected in feedback on student writing: An empirical study of secondary school teachers in five countries. International Review of Applied Linguistics in Language Teaching, 45, 69-94

Gibbs, G., \& Simpson, C. (2004). Conditions under which assessment supports students' learning. Learning and Teaching in Higher Education, 1, 3-31

Goldstein, L., \& Conrad, S. (1990). Student input and negotiation of meaning in ESL writing conferences. TESOL Quarterly, 24, 443-460

Goldstein, L. (2001). For Kyla: What does the research say about responding to ESL writers. In T. Silva, \& P. Matsuda, (eds.), On second language writing. Mahwah, NJ: Lawrence Erlbaum. pp. 73-90

Goldstein, L. (2004). Questions and answers about teacher written commentary and student revision: Teachers and students working together. Journal of Second Language Writing 13(1), 63-80

Goldstein, L. (2006). In search of the individual: Feedback and revision in second language writing. In K. Hyland \& F. Hyland (eds.), Feedback in second language writing: Contexts and issues (pp. 185-205). Cambridge: Cambridge University Press.

Grami, G. (2005). The effect of teachers' written feedback on ESL students' perception: A study in a Saudi ESL university-level context. Annual Review of Education, Communication and Language Sciences, 2. [Online] Available: http://research.ncl.ac.uk/ARECLS/vol2_documents/Grami/grami.htm

Hammond, J. (Ed.). (2002). Scaffolding teaching and learning in language and literacy education. Newtown: PETA.

Hedgcock, J., \& Lefkowitz, N. (1994). Feedback on feedback: Assessing learner receptivity in second language writing. Journal of Second Language Writing, 3, 141-163

Hedgcock, J., \& Lefkowitz, N. (1996). Some input on input: Two analyses of student response to expert feedback on L2 writing. Modern Language Journal, 80, 287-308

Horowitz, D. (1986). Process, not product: Less than meets the eye. TESOL Quarterly, 20, 141-144

Hounsell, D. (1987). Essay-writing and the quality of feedback'. In Richardson, J. T. E. et al., (eds.), Student Learning: Research in Education and Cognitive Psychology. Milton Keynes: SRHE \& Open University Press. pp. 109-119

Hyland, F. (1998). The impact of teacher written feedback on individual writers. Journal of Second Language Writing, 7(3), 255-286

Hyland, F. (2000). ESL writers and feedback: giving more autonomy to students. Language Teaching Research, 4(1), 33-54

Hyland, K. (2002). Teaching and researching writing. London: Longman.

Hyland, K. (2003). Second language writing. Cambridge: Cambridge University Press. http://dx.doi.org/10.1017/CBO9780511667251

Hyland, K. (2004). Genre and second language writing. Ann Arbor, MI: The University of Michigan Press.

Hyland, K. (2007). Genre pedagogy: Language, literacy and L2 writing instruction. Journal of Second Language Writing, 16(3), 148-164

Hyland, K., \& Hyland, F. (2006). Feedback in second language writing: Contexts and issues. Cambridge: Cambridge University Press.

Jacobs, G., Curtis, A., Briane, G., \& Huang, S. (1998). Feedback on student writing: Taking the middle path. Journal of Second Language Writing, 7(3), 307-317

James, C. (1998). Errors in language learning and use: Exploring error analysis. London: Longman.

John, A. M. (1998). Genre and pedagogical purposes. Journal of Second Language Writing, 4, 181-190

Johns, A. (2002). Genre in the classroom: Multiple perspectives. Mahwah, NJ: Lawrence Erlbaum. 
Keh, C. (1990). Feedback in the writing process: A model for methods of implementation. ELT Journal, 44(4), 294-304

Lalande, J. F. (1982). Reducing composition errors: An experiment. Modern Language Journal, 66(2), 140-149

Lantolf, J. (Ed.). (2000). Sociocultural theory and second language learning: Recent advances. Oxford: Oxford University Press.

Lantolf, J. P., \& Appel, G. (1994). (Eds.). Vygotskian Approaches to Second Language Research. Norwood, N.J.: Ablex Publishing.

Lantolf, J. P., \& Pavlenko, A. (1995). Sociocultural theory and second language acquisition. Annual Review of Applied Linguistics, 15, 108-124

Lave, J., \& Wenger, E. (1991). Situated learning: Legitimate peripheral participation. Cambridge: Cambridge University Press.

Lea, M. R., \& Street, B. V. (2000). Student writing and staff feedback. In M. R. Lea, \& B. Stierer (Eds), Student Writing in Higher Education (pp. 32-46). Buckingham: Open University Press.

Lee, I. (2005). Error correction in the L2 writing classroom: What do students think? TESL Canada Journal, 22(2), $1-16$

Lefkowitz, N. (2008). Writing the wrongs: Foreign and heritage language instructors' quest for accuracy. Paper presented at the 2008 Symposium on Second Language Writing, Purdue University, West Lafayette, IN.

Leki, I. (1991). The preferences of ESL students for error correction in college level writing classes. Foreign Language Annals, 24(3), 203-18

Leki, I. (1992). Understanding ESL writers. Portsmouth, NH: Heinemann.

Long, M. (1996). The role of the linguistic environment in second language acquisition. In R. Ritchie, \& T. Bhatia (eds.), Handbook of second language acquisition. San Diego, CA: Edward Arnold. pp. 413-468

McGroarty, M. (1992). Cooperative learning: The benefits for content area teaching. In P.A. Richard \& M.A. Snow (Eds.), The multicultural classroom: Readings for content-area teachers (pp. 58-69). White Plains, NY: Longman.

Montgomery, J., \& Baker, W. (2007). Teacher-written feedback: Student perceptions, teacher self-assessment, and actual teacher performance. Journal of Second Language Writing, 16, 82-99

Murphy, S. (2000). A sociocultural perspective on teacher response: Is there a student in the room? Assessing Writing 7(1), 79-90

Nassaji, H., \& Swain, M. (2000). A Vygotskian perspective on corrective feedback: The effect of random versus negotiated help on the learning of English articles. Language Awareness, 9, 34-51

O'Donnell, M. (2007). Policies and practices in foreign language writing at the college level: Survey results and implications. Foreign Language Annals, 40, 650-671

Oladejo, J. A. (1993). Error correction in ESL: Learners' preference. TESL Canada Journal, 10(2), 71-89

Patton, M. Q. (2002). Qualitative research and evaluation methods. Thousand Oaks: Sage Publications.

Pritchard, A., \& Woolward, J. (2010). Psychology for the classroom: Constructivism and social learning. New York: Routledge.

Prior, P. (2006). A sociocultural theory of writing. In C. A. MacArthur, S. Graham, \& J. Fitzgerald (Eds.), Handbook of writing research (pp. 54-66). New York: The Guilford Press.

Radecki, P. M., \& Swales, J. M. (1988). ESL student reaction to written comments on their written work. System, 6(3), 355-365

Reid, J. (1998). "Eye" learners and "ear" learners: Identifying the language needs of international student and U.S. residents writers. In P. Byrd, \& J. M. Reid, Grammar in the composition class: Essays on teaching ESL for college-bound students (pp. 3-17). Boston: Heinle \& Heinle.

Riazi, A. (1997). Acquiring disciplinary literacy: A sociocognitive analysis of text production and learning among Iranian graduate students of education. Journal of Second Language Writing, 6(2), 105-137

Robb, T., Ross, S., \& Shortreed, I. (1986). Salience of feedback on error and its effect on EFL writing quality. TESOL Quarterly, 20, 83-95

Rogoff, B. (1990). Apprenticeship in thinking. Cognitive development in social context. New York: Oxford 
University Press.

Rogoff, B. (1998). Cognition as a collaborative process. In W. Damon, D. Kuhn, \& R. S. Siegler (Eds.), Cognition, perceptions and language ( $5^{\text {th }}$ edition). (pp. 679-744). New York: John Wiley \& Sons.

Russell Valezy, J., \& Spada, N. (2006). The effectiveness of corrective feedback for second language acquisition: A meta-analysis of the research. In J. Norris, \& L. Ortega (Eds.), Synthesizing research on language learning and teaching (pp. 133-164). Amsterdam, The Netherlands: John Benjamins.

Saito, H. (1994). Teachers' practices and students' preferences for feedback on second language writing: A case study of adult ESL learners. TESL Canada Journal, 11(2), 46-70

Schulz, R. A. (2001). Cultural differences in student and teacher perceptions concerning the role of grammar instruction and corrective feedback: USA-Columbia. Modern Language Journal, 85, 244-258

Schultz, K. (2006). Qualitative research on writing. In C. A. MacArthur, S. Graham, \& J. Fitzgerald (Eds.), Handbook of Writing Research (pp. 357-373). New York: Guilford Press.

Semke, H. D. (1984). Effects of the red pen. Foreign Language Annuals, 17, 195-202

Sheen, Y. (2007). The effect of focused written corrective feedback and language aptitude on ESL learners' acquisition of articles. TESOL Quarterly, 41(2), 255-283

Sommers, N. (1982). Responding to student writing. College Composition and Communication, 33, 148-156

Sperling, M., \& Freedman, S. W. (2001). Research on writing. In V. Richardson (Ed.), Handbook of research on teaching, $4^{\text {th }}$ edition (pp. 370-389). Washington, DC: American Educational Research Association.

Stesenko, A., \& Arievitch, I. (2002). Teaching, learning and development: A post-Vygotskian perspective. In G. Wells and G. Glaxton (eds), Learning for life in the $21^{\text {st }}$ century sociocultural perspectives on the future of education (pp. 84-96). Oxford: Blackwell.

Stone, A. (1998). The metaphor of scaffolding: Its utility for the field of learning disabilities. Journal of Learning Disabilities, 3(4), 344-364

Straub, R. (1997). Students' reactions to teacher comments: An exploratory study. Research in the Teaching of English, 31(1), 91-119

Truscott, J. (1996). The case against grammar correction in L2 writing classes. Language Learning, 46(2), 327-369

Truscott, J. (1999). The case for "The case against grammar correction in L2 writing classes": A response to Ferris. Journal of Second Language Writing, 8(2), 111-122

Truscott, J. (2007). The effect of error correction on learners' ability to write accurately. Journal of Second Language Writing, 16(4), 255-272

Van Lier, L. (2000). From input to affordance: Social-interactive learning from an ecological perspective. In J. Lantolf, Sociocultural theory and second language learning: Recent advances (pp. 245-259). Oxford: Oxford University Press.

Vygotsky, L. S. (1978). Mind and society: The development of higher mental processes. Cambridge, MA: Harvard University Press.

Wenger, E. (1998). Communities of Practice. Learning, meaning and identity. Cambridge: Cambridge University Press.

Whitfield, B., \& Pollard, J. (1998). Awarness raising in the Saudi Arabian classroom. In J. C. Richards (Ed), Teaching in Action (pp. 143-149). Alexandria: TESOL.

Zamel, V. (1985). Responding to student writing. TESOL Quarterly, 19(1), 79-99

\section{Appendix A. Semi-Structured Interview Questions}

1. What is your opinion about the feedback you receive right now? Please support your comments with examples.

2. Do you think that the feedback you currently receive matches your needs? How so?

3. Could you comment on your teacher's practices regarding feedback?

4. What, in your opinion, impedes the feedback process? 
5. Please complete the following sentence: For the feedback to be helpful it should

6. Would you like to add other comments?

\section{Appendix B. Interviewees}

\begin{tabular}{|c|c|c|c|l|}
\hline Name & Sex & Age & $\begin{array}{c}\text { English Proficiency } \\
\text { Level }\end{array}$ & \multicolumn{1}{|c|}{ Previous Education Context } \\
\hline Ali & M & 22 & IELTS Prep. 1* & $\begin{array}{l}\text { B.Eng in Mechanical Engineering (KSA): } \\
\text { Medium of instruction was entirely English. } \\
\text { Studied three writing courses at university. }\end{array}$ \\
\hline Muneerah & F & 30 & IELTS Prep. 1 & $\begin{array}{l}\text { B.Sc. Physics (KSA): Medium of instruction } \\
\text { was a mixture of English and Arabic. No } \\
\text { special writing courses before except for } \\
\text { Univ Eng. (101) and (112). }\end{array}$ \\
\hline Jawaher & F & 24 & IELTS Prep. 2 & $\begin{array}{l}\text { B.A Early childhood education (Egypt): } \\
\text { Medium of instruction was entirely Arabic. } \\
\text { Basic writing courses in the U.K during } \\
\text { summer holidays and Eng. (101) }\end{array}$ \\
\hline Majid & M & 35 & IELTS Prep. 3 & $\begin{array}{l}\text { MBA (Malaysia): Medium of instruction was } \\
\text { entirely English. Special writing courses for } \\
\text { Business. }\end{array}$ \\
\hline Abdullah & M & 25 & IELTS Prep. 3 & $\begin{array}{l}\text { M.A International Law (Jordan): Medium of } \\
\text { instruction was entirely a mixture of Arabic } \\
\text { and English. Special writing courses for } \\
\text { lawyers. }\end{array}$ \\
\hline
\end{tabular}

